\title{
Lateglacial and early-Holocene environments of Novaya Zemlya and the Kara Sea Region of the Russian Arctic
}

\author{
Leonid Serebryanny, Andrei Andreev, Evgeniya Malyasova, \\ Pavel Tarasov and Fedor Romanenko
}

\author{
(Institute of Geography, Russian Academy of Sciences, Staromonetny Pereulok \\ 29, Moscow 109017, Russia)
}

Received 5 August 1996, revised manuscript accepted 9 September 1997

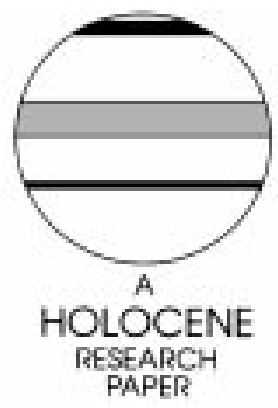

Introduction

The Quaternary evolution of northernmost Russia has been a subject of continuous debates, mostly due to the lack of empirical data. The speculative hypothesis that a huge Panarctic Ice Sheet (Denton and Hughes, 1981) covered this area for much of the late Quaternary has haunted studies of northern high latitudes for far too long and hindered scientific progress. Pollen and radiocarbon data recently obtained from several sites in the polar islands and mainland coastal areas (Figure 1) present a more realistic view of past environments in the Russian Arctic during the last 16000 years.

The subdivision of high-latitude vegetation is given here according to the Russian traditional scheme (Isachenko and Shlyapnikov, 1989). The vegetation of polar deserts is sparse and consists of lichens, mosses and some vascular plants (Cyperaceae, Poaceae, herbs - up to 50-60 species in total). As one moves southwards, the vegetation cover becomes denser and more differentiated; the number of species of vascular plants attains 150 180 in Arctic tundra, and dwarf shrubs occur almost everywhere. Typical tundra is a realm of treeless assemblages with herbs, Poaceae, Cyperaceae and dwarf shrubs (Salix, Betula). The moss flora is enriched by several Sphagnum species. Southern tundra is characterized by an increased role of shrubs. This simplified division is rather clearly reflected in modern pollen rain and fossil spectra. Problems of correlation between modern plant cover and pollen spectra in such polar archipelago as Sptisbergen (Svalbard) have been treated in other papers (Serebryanny et al., 1985; 1993).

\section{Novaya Zemlya}

Novaya Zemlya is a large polar archipelago that today is occupied by mountains, glaciers and ice caps. Northern coastlands and higher elevations (above 200-250 m) are polar deserts, whereas other areas support Arctic tundra. The only exception is typical tundra at the extreme southwest portion of the archipelago.

Extensive solifluction flows are common on the mountain slopes and coastal cliffs of Novaya Zemlya. Terrace units are often buried and therefore not distinguishable. Nevertheless, organic layers, mostly peat lenses, were identified in situ in some localities during geological surveys. One of these sections is located near Cape Nikolayevsky in the northern part of Gusinaya Zemlya - 'goose land' $\left(72^{\circ} 10^{\prime} \mathrm{N}, 52^{\circ} 16^{\prime} \mathrm{E}, 1.3 \mathrm{~m}\right.$ a.s.1.), a large peninsula in the southwest of the Southern Island. Two peat layers were exposed in lacustrine deposits with the lower peat being dated to $15310 \pm 610 \mathrm{yr}$ BP (LU-1187).

Pollen spectra of this section (Figure 2) contain numerous grains of Cyperaceae, Poaceae and other herbaceous plants, including such relatively thermophilous species as Rubus chamaemorus, Polemonium boreale, Valeriana capitata and Polygonum viviparum. Dwarf birch (Betula nana) pollen attains $28 \%$. Bryales spores are abundant (up to $35 \%$ ). Single Ericales grains and a 


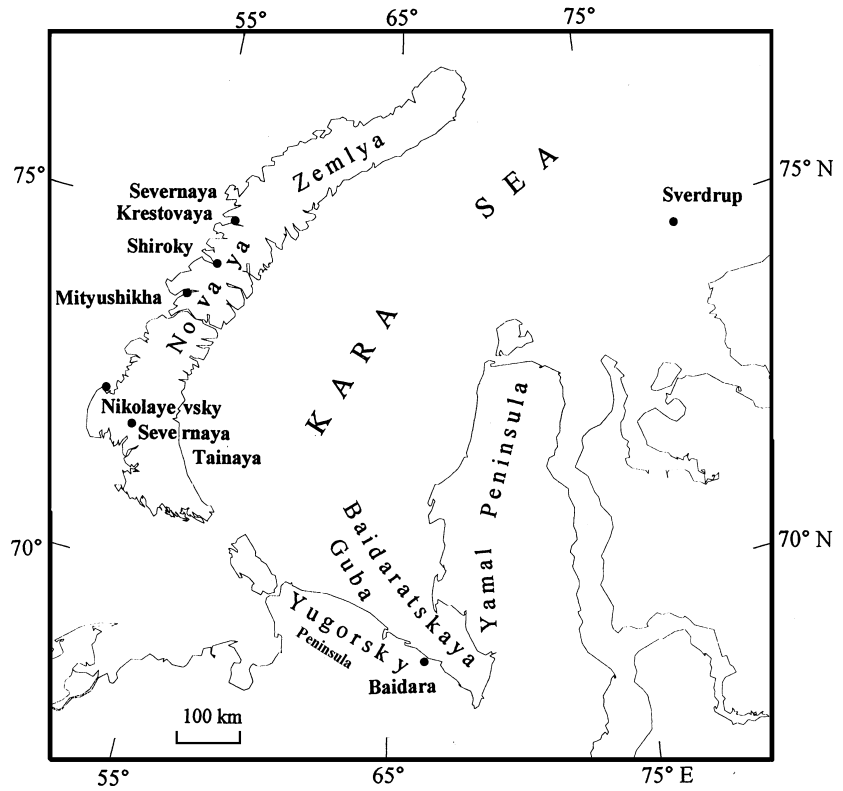

Figure 1 Location map of the area in study.

considerable amount of wormwood (Artemisia) pollen were found in the lowermost part of the section. These spectra are similar to subfossil spectra of typical tundra. It is remarkable that the present flora of Gusinaya Zemlya has a great abundance and diversity of flowering plants as compared to other regions of Southern Island (Yuriev, 1926). Betula nana grows commonly in this region now.
Similar information was obtained from a buried peat exposed along the coast of Mityushikha Bay $\left(73^{\circ} 40^{\prime} \mathrm{N}, 54^{\circ} 48^{\prime} \mathrm{E}, 65 \mathrm{~m}\right.$ a.s.l.). A single radiocarbon date of $15120 \pm 120 \mathrm{yr}$ BP (LU1446) was obtained. Here we found an assemblage dominated by Cyperaceae and Poaceae pollen and spores of Bryales (Figure 3). The floristic composition of nonarboreal pollen was very diverse: in addition to pure periglacial taxa (Ranunculus arcticus, Dryas octopetala, D. punctata, Minuartia arctica, Epilobium arcticum and others) pollen from more thermophillous plants (Rubus chamaemorus, Polemonium boreale, Valeriana capitata, Polygonum viviparum) was also present. The considerable admixture of long-distance wind-blown pollen (Pinus, Picea, Betula) indicates the northward migration of tree limit on the mainland. In all samples, single Salix pollen grains were identified. Dwarf Salixherbaceous communities evidently characterized the coastal region, not far from the modern glacial limits, $c .15000 \mathrm{yr}$ BP.

Nonglacial conditions existed in some inner areas of Novaya Zemlya as well. For example, in the Severnaya Tainaya River valley, Southern Island (site $3031,71^{\circ} 46^{\prime} \mathrm{N}, 53^{\circ} 10^{\prime} \mathrm{E}$ ), a peat horizon $2.2 \mathrm{~m}$ thick was found and investigated $22 \mathrm{~km}$ from the present-day sea coast. The basal gyttja is characterized by abundant pollen of Cyperaceae and herbs (Figure 4). Poaceae pollen is less abundant than in the above mentioned sites. However, this assemblage is typical of periglacial environments and therefore likely dates to glacial times.

The topmost peat layer was deposited during the Holocene. This pollen assemblage contains pollen of dwarf Betula (21\%), Salix, including S. polaris, Cyperaceae (up to $20 \%$ ) and Bryales spores. The herbaceous pollen is represented only by single

\section{Nikolayevsky site, Novaya Zemlya}

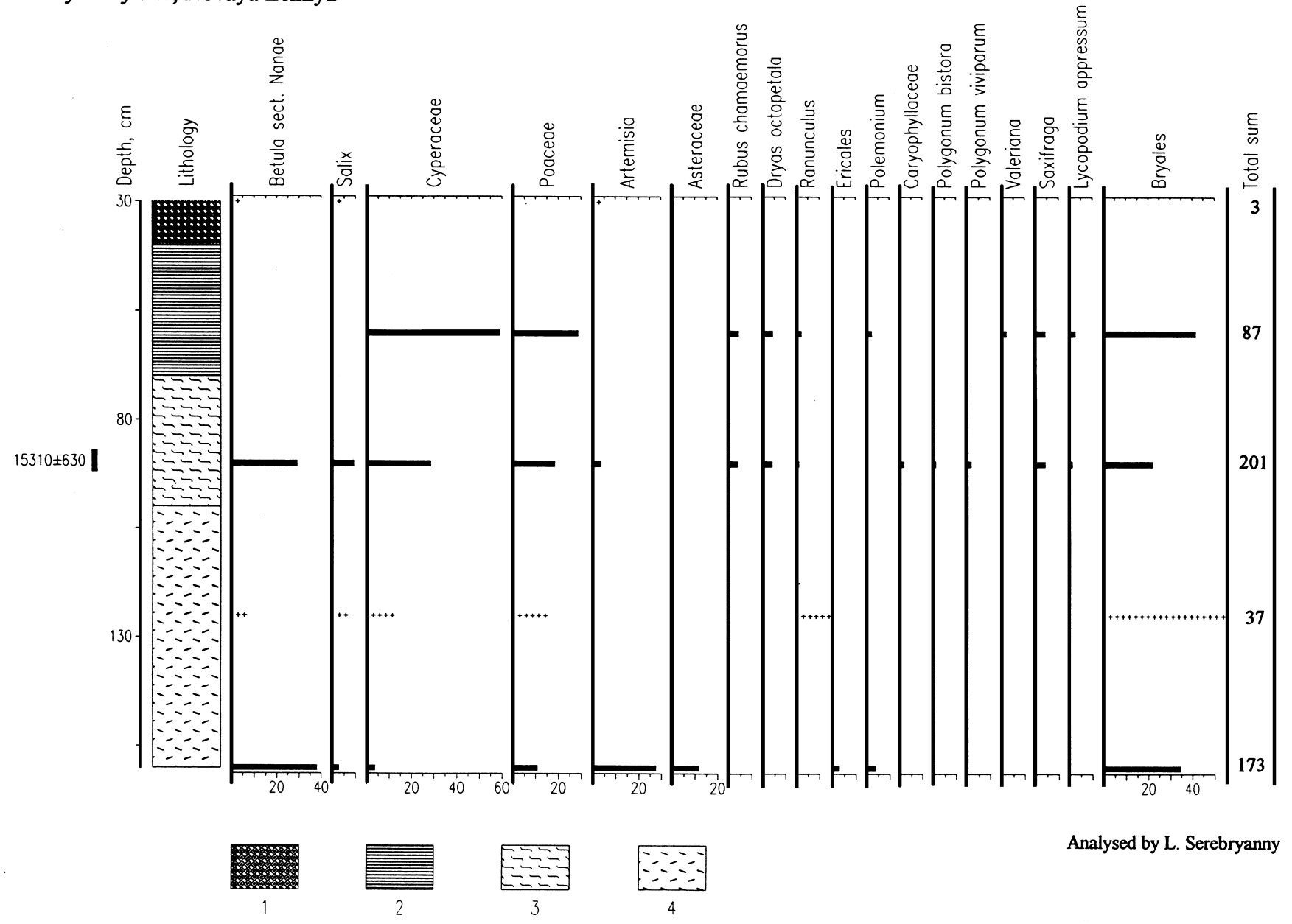

Figure 2 Pollen diagram of organogenic and littoral deposits near Nikolayevsky Cape, Gusinaya Zemlya, Southern Island of Novaya Zemlya. Pollen values are expressed as percentages of total pollen. (1) Gravelly loam; (2) clay; (3) highly mineralized peat; (4) sandy loam. 


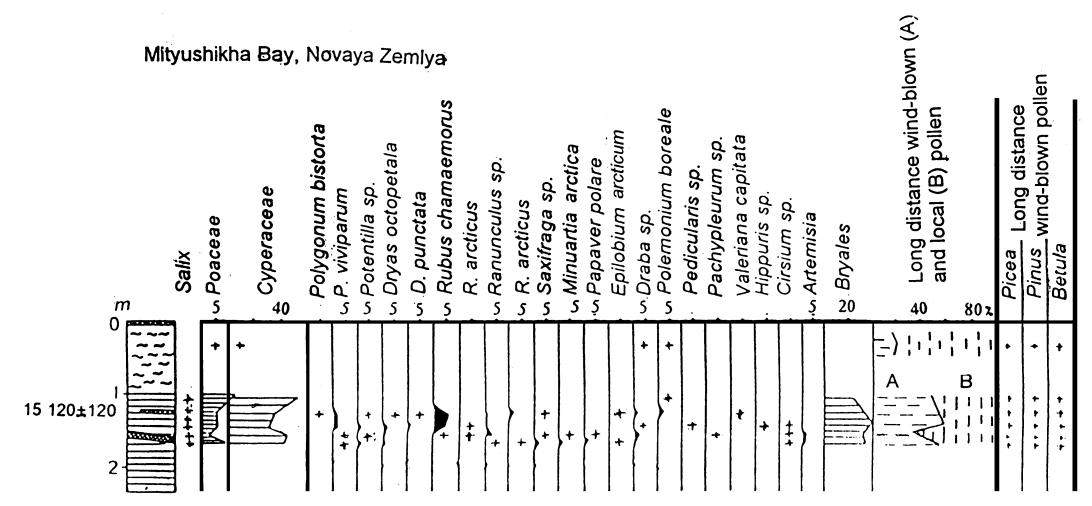

$\approx \sim \approx 0{ }^{2}{ }^{2}$

Figure 3 Pollen diagram of organogenic deposits at the coast of Mityushikha Bay, Northern Island of Novaya Zemlya (Malyasova and Serebryanny, 1993). Pollen values are expressed as percentages of total pollen. (1) Loam; (2) clay; (3) peat.

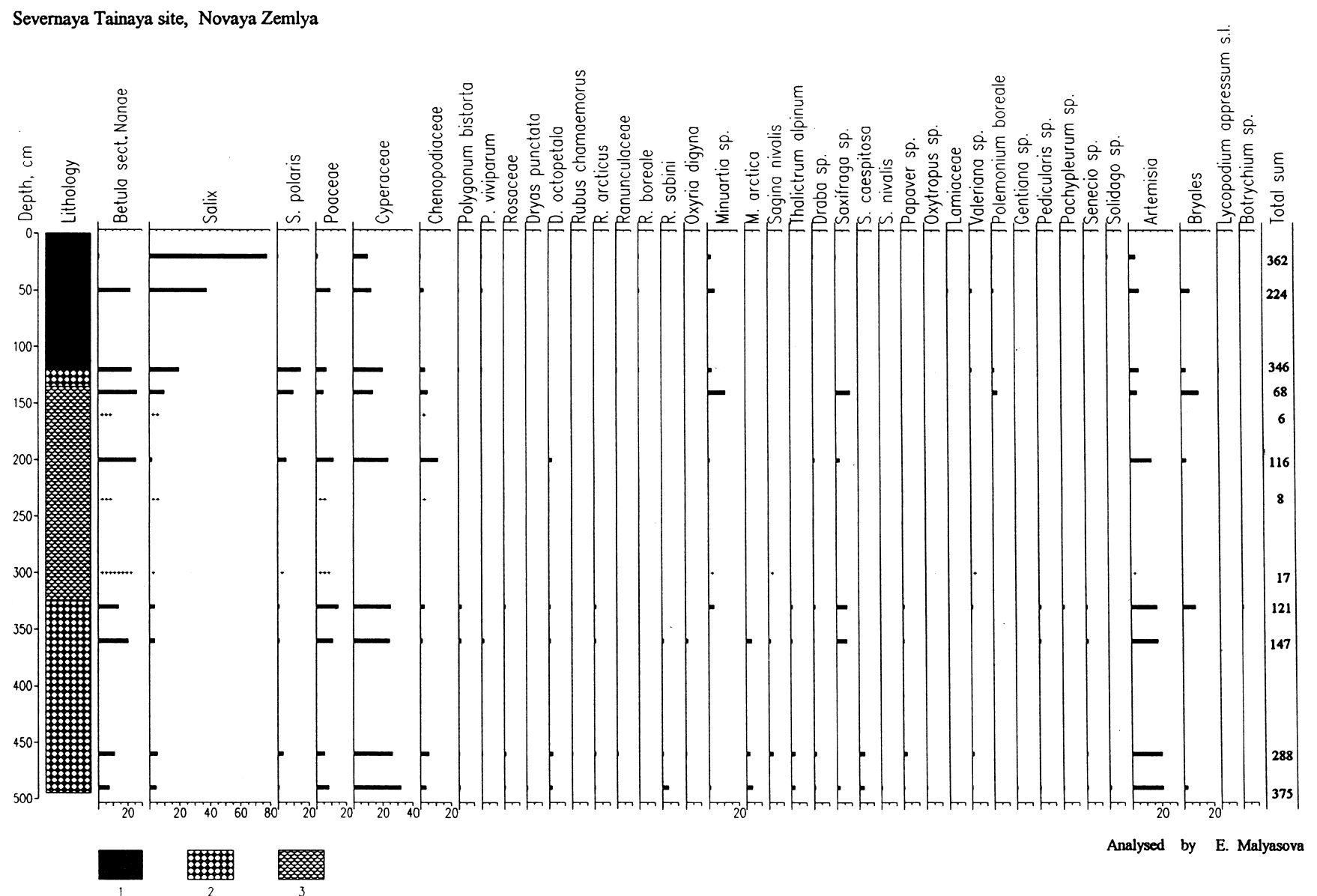

Figure 4 Pollen diagram of organogenic and littoral deposits in the valley of Severnaya Tainaya River, Southern Island of Novaya Zemlya. Pollen values are expressed as percentages of total pollen. (1) Peat; (2) sandy gyttja; (3) gravelly gyttja.

grains, which belong to mainly Arctic plants, such as Polygonum viviparum, Ranunculus boreale, Minuartia sp., Saxifraga sp. and Polemonium boreale. We suppose an early-Holocene age of these sediments due to their similarity with the basal layers of radiocarbon dated site 2573 .

This site (2573), located in the valley of Severnaya Krestovaya River, Northern Island $\left(74^{\circ} 08^{\prime} \mathrm{N}, 56^{\circ} 30^{\prime} \mathrm{E}\right)$, contains valuable information about early-Holocene palaeoenvironments in Novaya Zemlya. Silt with occasional pebbles and marine shells was exposed above basal gravel and sand and covered by peat layers with clay and loam, about $1.6 \mathrm{~m}$ thick. A considerable amount of pollen and spores was identified in the peat samples. Extremely abundant Bryales spores are a typical feature of this section (Figure 5).

Dwarf Betula pollen is rather abundant in almost all the spectra $(12-19 \%)$ and in the lowest one even up to $58 \%$. The palynoflora of the lower peat samples represents a wide range of environments. Besides the Hypoarctic species Betula nana, other taxa groups, including Boreal (Vaccinium sp.) and Arctic (Dryas octopetala, Rumex arcticus, Draba incana) were identified here. The finds of Chenopodiaceae and Artemisia pollen indicates the occurrence of dry and coastal biotopes. A radiocarbon age of $10550 \pm 160 \mathrm{yr}$ BP (LU-1466) suggests that these sediments are of Younger Dryas age. 


\section{Severnaya Krestovaya site, Novaya Zemlya}

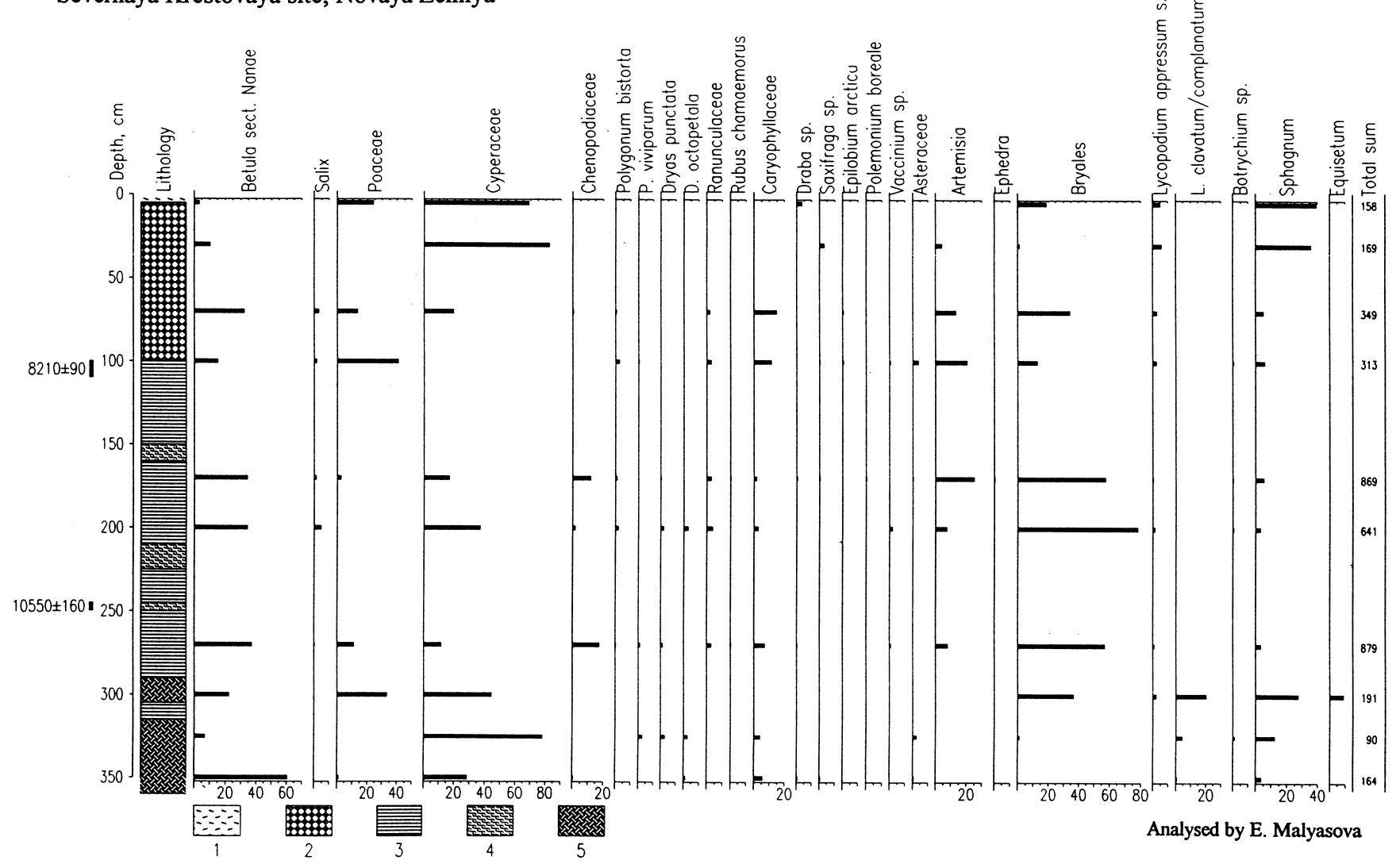

Figure 5 Pollen diagram of organogenic and littoral deposits in the valley of Severnaya Krestovaya River, Northern Island of Novaya Zemlya. Pollen values are expressed as percentages of total pollen. (1) Gravelly loam; (2) peat; (3) silt; (4) loam; (5) clay.

The middle peat layers contain pollen of different taxa: steppic (Ephedra, some Chenopodiaceae and Artemisia), Boreal (Polygonum bistorta), Hypoarctic (Betula nana, Rubus chamaemorus) and Arctic (Draba incana, Saxifraga sp., Polemonium sp.). These taxa suggest a possible correlation with sediments dated to the Preboreal period on the Kola Peninsula-White Sea Region (Malyasova, 1976).

The upper peat contains more Cyperaceae, Poaceae and Artemisia pollen than is typical for early-Holocene pollen assemblages from northeast Europe/northwest Asia. At the same time, quantity of long distance Pinus pollen suggests a considerable northward migration of trees on the mainland. A radiocarbon age of $8210 \pm 90$ yr BP (LU-1462) indicates that deposition took place during the Boreal period.

A $4.5 \mathrm{~m}$ exposure of silts and clays covered by till is located near the margin of Shiroky Glacier at the coast of Mashigina Guba, Northern Island (55-60 $\mathrm{m}$ above sea level, $74^{\circ} 45^{\prime} \mathrm{N}$, $55^{\circ} 10^{\prime} \mathrm{E}$ ). Wood fragments found in the uppermost part of this sequence are dated to $8160 \pm 70 \mathrm{yr}$ BP (LU-1761). According to the pollen data (Figure 6), this time was characterized by high percentages of Cyperaceae pollen and Bryales spores, but pollen of Betula nana, Salix, Poaceae and Caryophyllaceae occurs in significant amounts. These spectra indicate that at least a typical tundra grew at the central western coast of Northern Island.

A till which overlies this silt was perhaps formed during a sudden, surge-like advance of Shiroky Glacier (there are morphological indications of several stages in this catastrophic process). Pollen of Pinus and Betula was found in six samples from the till section. Pollen spectra from the Vavilov Ice Cap, October Revolution Island, Severnaya Zemlya, also contain grains of Pinus and Betula as well as Alnus and Corylus. A. Andreev who analysed these samples supposes that such results are rather typical for recent spectra from the Kara Sea Region. Probably, the surge of Shiroky Glacier was very young.
In summary, Lateglacial and early-Holocene dwarf-shrub communities with abundant herbs and Bryales were distributed widely in the southern part of the archipelago. It was a typical tundra, although some floristic elements persisted from the full glacial. Salix and Betula were the dominant dwarf shrubs. At the same time, Arctic herbaceous-moss tundra was common in the northern regions of the archipelago. We hypothesize that the Lateglacial/Holocene transition was marked by a rather mild climate which was very favourable for vegetation development in high-latitude regions of Europe.

\section{Sverdrup Island, Kara Sea}

Sverdrup Island $\left(74^{\circ} 30^{\prime} \mathrm{N}, 79^{\circ} 30^{\prime} \mathrm{E}\right)$ is located on the Kara Sea Shelf, $110 \mathrm{~km}$ from the mainland. It has area of $70 \mathrm{~km}^{2}$, comprised mostly of sand spits with elevations to $2 \mathrm{~m}$ a.s.l. The highest point $(33 \mathrm{~m})$ is in the central part of the island. This surface consists of Quaternary terraces of gravels, sands and loams. Harsh climate limits vegetation growth and the island is dominated by polar deserts.

A buried peat horizon is exposed in the northern part of the island, 7-8 $\mathrm{m}$ a.s.l. and $6 \mathrm{~m}$ from the sea. It contains high concentrations of pollen in contrast to the over- and underlying sand layers where only very few pollen grains occur. The basal sands include ice veins that contain redeposited Mesozoic spores. These ice veins probably developed during the last ice age, when permafrost and aeolian processes were active on the dried Kara Sea shelves.

The bottom of the peat layer, $0.8-0.9 \mathrm{~m}$, was radiocarbon dated to $11640 \pm 40 \mathrm{yr}$ BP (GIN-7625). Therefore, the accumulatio of Cyperaceae peat began during the Allerød. The composition onf palynospectra (Figure 7) suggests the presence of typical tundra communities with Poaceae, Cyperaceae, Salix, Ranunculaceae, Rosaceae, Polygonum, Valeriana, Caryophyllaceae and Bryales. 


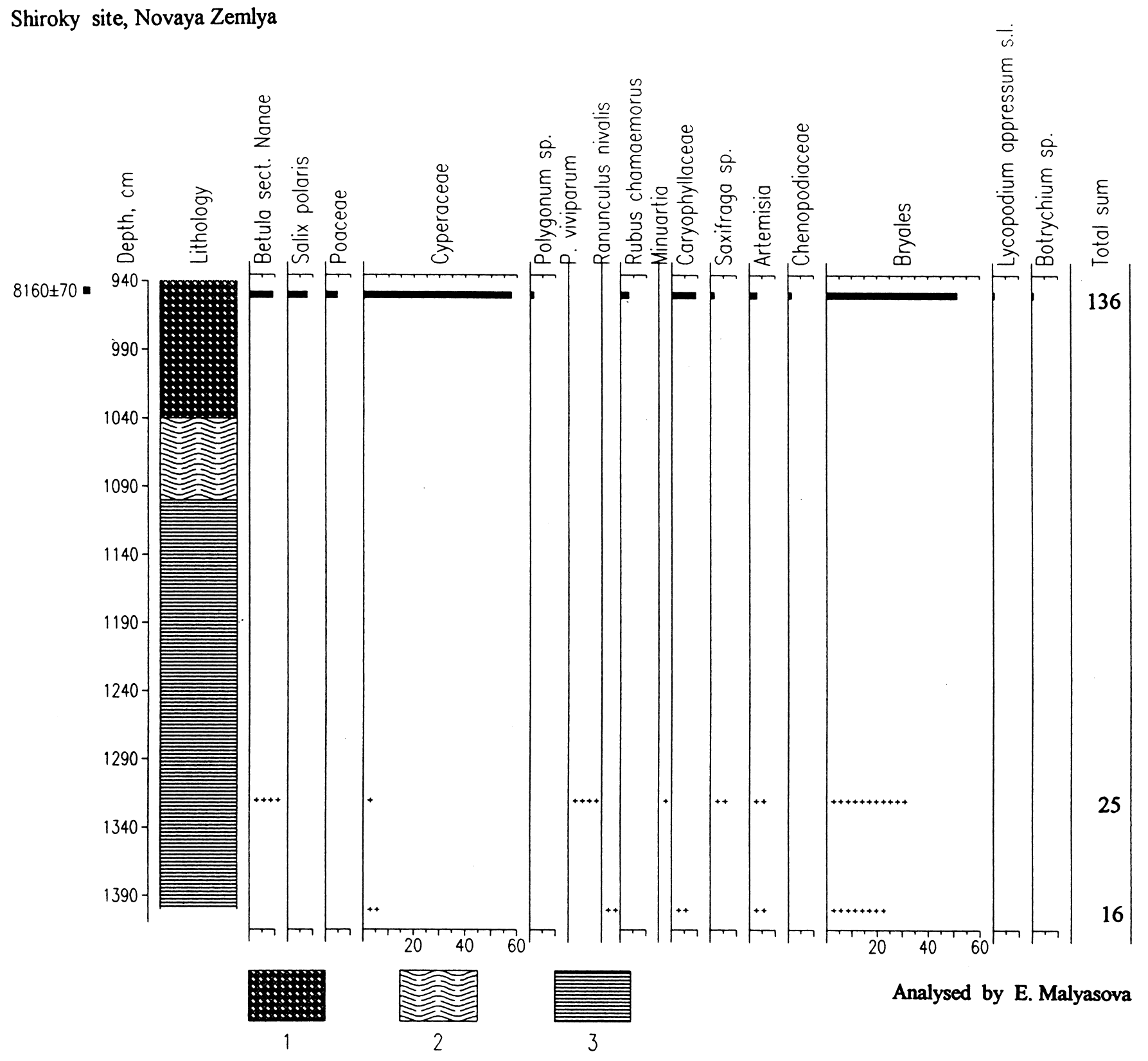

Figure 6 Pollen diagram of proglacial lacustrine deposits near Shiroky Glacier, Mashigina Guba, Northern Island of Novaya Zemlya. Pollen values are expressed as percentages of total pollen. (1) Silt with wood fragments; (2) loam; (3) clay.

Steppe-like associations indicated by Artemisia, Chenopodiaceae and Asteraceae also existed in some drier localities.

The Younger Dryas cooling is reflected in the increased share of Artemisia, Chenopodiaceae and Salix pollen and Bryales spores simultaneously. Peat from $0.55-0.65 \mathrm{~m}$ depth was radiocarbon dated to $10490 \pm 380 \mathrm{yr}$ BP (GIN-7626). The greater admixture of Artemisia and Chenopodiaceae pollen indicates that the climate was much drier. Finds of pollen grains of Salix and Betula of the Nanae section as well as macrofossil remains of Betula indicate the importance of these shrubs on the landscape. The climate became less wet than in the Allerød. A cold and dry climate is confirmed also by the occurrence of pollen of Betula of the Albae section.

The early Preboreal warming was marked by a sudden change in the pollen spectra: pollen of trees and shrubs became dominant and pollen of Artemisia and Chenopodiaceae disappeared. Macroscopic remains of Betula are absent: probably the increased waterlogging caused the decay of shrub coenoses on the swamp surface. Radiocarbon dating of the upper peat sample at $9770 \pm 280 \mathrm{yr} \mathrm{BP}$ (GIN-7627) as well as the above-mentioned dating of the lower peat sample (GIN-7626) indicates the beginning of this warm interval.

The early Preboreal vegetation on Sverdrup Island area probably approximated modern southern tundra. Dwarf Betula, Ericales and even probably Alnus fruticosa were growing there in contrast to the present situation. Abundant pollen of arboreal Betula was totally long transported, and the tree-line may have occupied a more northerly position on the mainland in the early Preboreal than nowadays.

Climate was more favourable to plant growth compared to the above mentioned Novaya Zemlya conditions. Evidently, this climate amelioration was connected with the general sea-level rise and the penetration of Atlantic air masses and sea currents eastward to the Barents and Kara seas.

\section{Western coast of Baidaratskaya Guba, Yugorsky Peninsula}

This coastland consists of five terraces uplifted to $0.5-2.5 \mathrm{~m}$ (laida), 4-8 m (1st level), 10-18 m (2nd level, 25-40 m (3rd level) 


\section{Sverdrup Island site, Kara Sea}

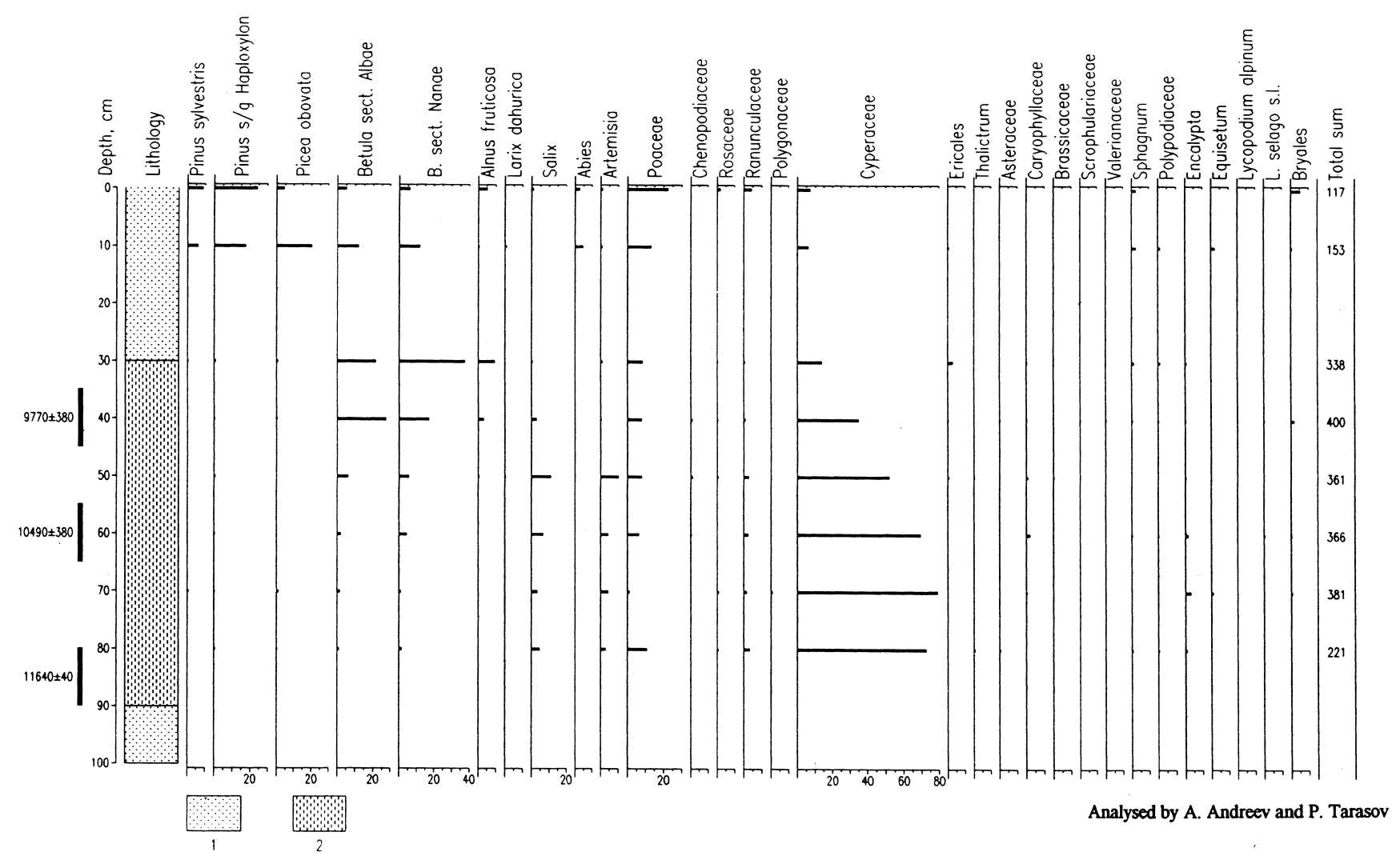

Figure 7 Pollen diagram of organogenic deposits in the Sverdrup Island. Pollen values are expressed as percentages of total pollen. (1) Sand; (2) peat.

and $45-65 \mathrm{~m}$ (4th level). The three lower terraces have a marine origin and developed during the Holocene. The relief of the third terrace is closely connected with permafrost: underground ice horizons and veins influence the character of the surface.

A peat horizon was exposed in the 3rd level terrace near Yary $\left(69^{\circ} 00^{\prime} \mathrm{N}, 66^{\circ} 40^{\prime} \mathrm{E}\right)$. It overlies grey fine-grained sands with gravels. Diatom analyses of these sediments (by Z.V. Aleshinskaya) confirm their alluvial character. Pollen spectra of these deposits (depth 6.2-10.3 m) contain considerable amounts of redeposited pollen of Abies, Picea, Pinus subgenus Haploxylon, P. subgenus Diploxylon, Tilia, Corylus and Juglans. Similar spectra were assigned to the Mikulino (Riss-Wurm) Interglacial in the Pai-Khoi Range (Duryagina and Konovalenko, 1993), but some grains (Juglans) have a definite pre-Quaternary origin. The pollen of Betula nana, Artemisia, Poaceae, Ericales and other taxa do not occur frequently. Probably during the time of sedimentation there was an open landscape of polar deserts with very meagre and sparse vegetation in the area under study.

The middle part of this section (4.2-6.2 m) contains more finegrained sediments (silts and clays with ice particles) which accumulated in shallow oxbows. The amount of exotic grains from Alnus fruticosa and Betula sect. Albae, and Lycopodium alpinum spores was considerable, but the occurrence of redeposited pollen and spores was less frequent. The deposition rates became relatively low when the nearby vegetation produced enough pollen and spores to dominate in spectra.

Palynological data (Figure 8) indicate that sparse Betula tree stands grew at the western coast of Baidaratskaya Guba. The presence of Alnus fruticosa and Betula nana as well as Lycopodium alpinum was considerable. The vegetation very much resembled the present forest-tundra with a dense lichen cover. The Late Pleistocene age of sediments is confirmed by radiocarbon dating. The upper layer of the section was covered by loamy and silty lenses enriched by wood remains, stumps and twigs, $4-6 \mathrm{~cm}$ in diameter.
One such enrolled branch of Alnus fruticosa, $6 \mathrm{~cm}$ in diameter, was radiocarbon dated at $10900 \pm 120 \mathrm{yr}$ BP (MGU-1362). Sedimentation in an oxbow deposit took place in the Allerød and finished at the beginning of Younger Dryas.

The overlying peat consists of a series of lenses, each one up to several tens of metres in length and up to $4 \mathrm{~m}$ thick. Samples for pollen analysis were taken from the thickest lens. Radiocarbon datings of peat from the depth $4.10-4.15 \mathrm{~m}-8000 \pm 125 \mathrm{yr}$ BP (WAT-2924) - and from the depth 3.70-3.85 m - 8210 \pm 110 (GIN-7862a), $8120 \pm 90$ (GIN-7862b) and $8090 \pm 40 \mathrm{yr}$ BP (GIN$7862 \mathrm{c}$ ) - indicate that peat accumulation began about $8000-8200$ yr BP.

The results of the radiocarbon dating indicate a considerable break in sedimentation between 11000 and 8000-8200 yr BP. Perhaps deposits did not accumulate since the Younger Dryas because of changes in the fluvial regime. Furthermore, climate perhaps was not favourable for peat growth during the Preboreal and early Boreal. The situation changed in the late Boreal and Atlantic, when the climate warmed and the processes of peat accumulation increased. This new stage was marked by foresttundra development, but with less Alnus fruticosa followed by its almost complete disappearance around $7700 \mathrm{yr}$ BP. Cyperaceae peat was deposited in the very humid environments of the thermal maximum.

\section{Conclusion}

In the light of the available pollen and radiocarbon data it is possible to reconstruct the Lateglacial and early-Holocene environments in the western part of the Russian Arctic. There is no evidence that huge ice sheets existed there, but certainly the ice cap of Novaya Zemlya could have been slightly more extensive than today (Pavlidis, 1992). Nevertheless the present western 


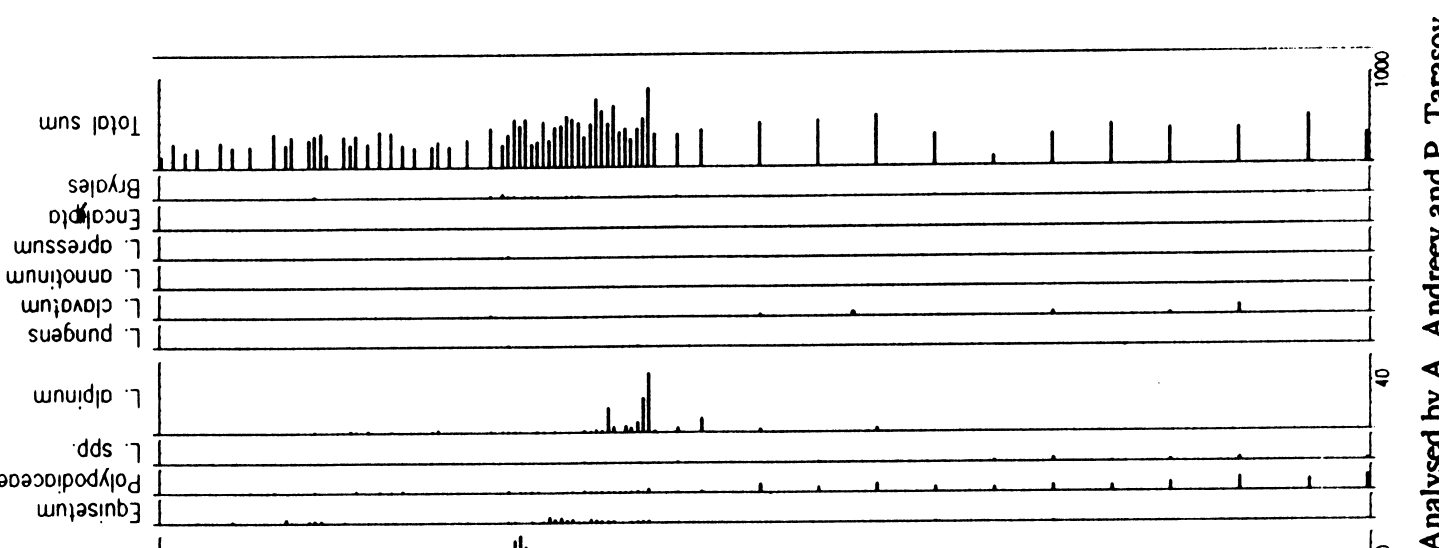

unubouds

ә0ә20160u

ว0ว501704ग!了

20азоләц八

วоәวо|кบ

sə|00!1]

un!uowalod

20200100|nydojas

uniuobjods

วоวว0!10 7 ! d do

aоวә0نобк10d

DuDija|0

ә0әวо|nวunuDy

แกมرํㅣㅇㅣ

20วว0s0y

ә0әэ0іродоuачว

ә0วз0ग!5s0נg

a0asoldy

2025090 1

20ว300d

oudk 1

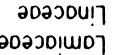

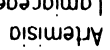

วоәวољวdk

$x$

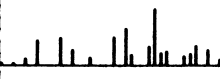

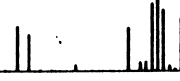

snwin

ㅇ‼!

sninos

saigr

$\times 1.07$

vo|kxoㅣ!ㅇ 6/s snu!!

uop $1 \times 0$ ddoH $6 / \mathrm{s}$ snu!d

0,0л090 Daग!d

osouinnib snuly

osoo!̣ny snum

dds snuily

...

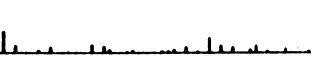

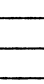


coastlands of this archipelago were ice-free and tundra communities with Betula nana grew in at least two areas under study 15 000-16 000 yrs BP. The Kara Sea shelf and southern coast lands were also ice-free and modified by intensive permafrost processes and erosion which caused the washing out of older preQuaternary layers.

The Lateglacial sensu stricto (13000-10300 yrs BP) was marked by the appearance of forest-tundra along the southern coast of Baidaratskaya Guba and tundra in Sverdrup Island. The large areas of the Kara Sea Shelf still had subaerial regime and were influenced by periglacial processes. Typical tundra existed even at the western coastlands of Novaya Zemlya in the Allerød.

We note the signs of a prominent climate amelioration in all the region under study during the early Holocene. Dwarf-shrub communities with abundant herbs and Bryales were distributed widely in Novaya Zemlya and the Kara Sea Shelf following the general rise in sea level. The early-Holocene thermal maximum was marked also in other high Arctic regions (Kaplina and Lozhkin, 1982; Ritchie et al., 1983; Makeev and Ponomareva, 1988; Clague and Matthews, 1989; Nikolayev and Kolokolov, 1992; Ukraintseva, 1992).

\section{Acknowledgements}

We are very grateful to Patricia M. Anderson, Hannu Hyvarinen and John Birks for valuable recommendations and kind assistance in presentation of our manuscript. Radiocarbon laboratories of Saint Petersburgh State University (Khikmatulla A. Arslanov), Geological Institute of Russian Academy of Sciences (Leopold D. Sulerzhitsky) and Moscow State University (Oleg Parunin) contributed by dating our samples.

\section{References}

Clague, J.J. and Matthews, R.W. 1989: Early Holocene thermal maximum in western North America: new evidence from Castle Peak, British Columbia. Geology 17, 277-80.

Denton, G. and Hughes, T., editors 1981: The last great ice sheets. New York: Wiley, $481 \mathrm{pp}$.
Duryagina, D.A. and Konovalenko, L.A. 1993: Pleistocene palynology of the north-west of the European part of Russia (Palinologiya pleistotsena Severo-Vostoka evropeiskoi chasti Rossii). Sankt-Peterburg: Nauka, 124 pp. (in Russian).

Isachenko, A.G. and Shlyapnikov, A.A. 1989: Landscapes. Moscow: Mysl, 505 pp.

Kaplina, T.N. and Lozhkin, A.V. 1982: History of the vegetation evolution at coastal lowlands of Yakutia during the Holocene (Istoriya razvitiya rastitelnosti primorskikh nizmennostei Yakutii v golotsene). In Evolution of the environment at the USSR territory during Late Pleistocene and Holocene (Razvitiye prirody territorii SSSR v pozdnem pleistocene $i$ golotsene), Moscow: Nauka, 207-20 (in Russian).

Makeev, V.M. and Ponomareva, D.P. 1988: The Holocene paleogeography of Kotelny Island. In International conference on the problems of the Holocene - abstracts, Tbilisi: Metsniereba, 64-65.

Malyasova, E.S. 1976: Palynology of the bottom sediments of the White Sea (Palinologiya donnykh otlozheniyi Barentseva morya). Leningrad: University Publishing House, 120 pp. (in Russian).

Malyasova, E.S. and Serebryanny, L.R. 1993: The natural history of Novaya Zemlya (Estestvennaya istoriya Novoi Zemli). In Boyarsky, P.V., editor, Novaya Zemlya 2, 10-22 (in Russian).

Nikolayev, V.A. and Kolokolov, S.L. 1992: Holocene climatostratigraphy based on oxygene isotope data (Klimatostratigrafiya golotsena po izotopno-kislorodnym dannym). News from the Academy of Sciences of the USSR. Ser. geol. 4, 145-51 (in Russian).

Pavlidis, Yu. A. 1992: The shelf of the world ocean during the Late Quaternary (Shelf Mirovogo okeana v pozdnechetvertichnoye vremya). Moscow: Nauka, 272 pp. (in Russian).

Ritchie, J.C., Cwynar, L.C. and Spear, R.W. 1983: Evidence from north-west Canada for early Holocene Milancovitch maximum. Nature $305,126-28$

Serebryanny, L.R. et al., 1985: Reconstruction of the development of vegetation in Arctic high latitudes. Polar Geography and Geology 9, $308-20$.

Serebryanny, L.R. et al., 1993: Palaeoecology of Arcto-Atlantic during the Holocene (Paleoekologiya Arkto-Atlantiki v golotsene). News from the Academy of Sciences of the USSR. Ser. geogr. 2, 39-52 (in Russian).

Ukraintseva, V.V. 1992: New paleobotanical and palinological evidences of Early Holocene climate warming on high latitude Arctic (Novye palynologicheskie i paleobotanicheskie svidetel'stva rannegolotsenovogo potepleniya v vysokikh shirotakh Arktiki). Botanichesky Zhurnal 75(1), 7073 (in Russian).

Yuriev, M.M. 1926: On the study of Novaya Zemlya peat boys (L voprosy obizuchenii novozemelskikh torfyanikov). News from Scientific Research Melioration Institute 10, 17-28 (in Russian). 